\title{
SAXTON PLUTONIUM PROJECT QUARTERLY PROGRESS LETTER \\ FOR THE PERIOD \\ ENDING SEPTEMBER 30, 1969
}

W. R. Smalley,

Project Engineer

Prepared for the New York Operations Office

U. S. Atomic Energy Commission

Under AEC Contract AT(30-1)-3385

November 1969
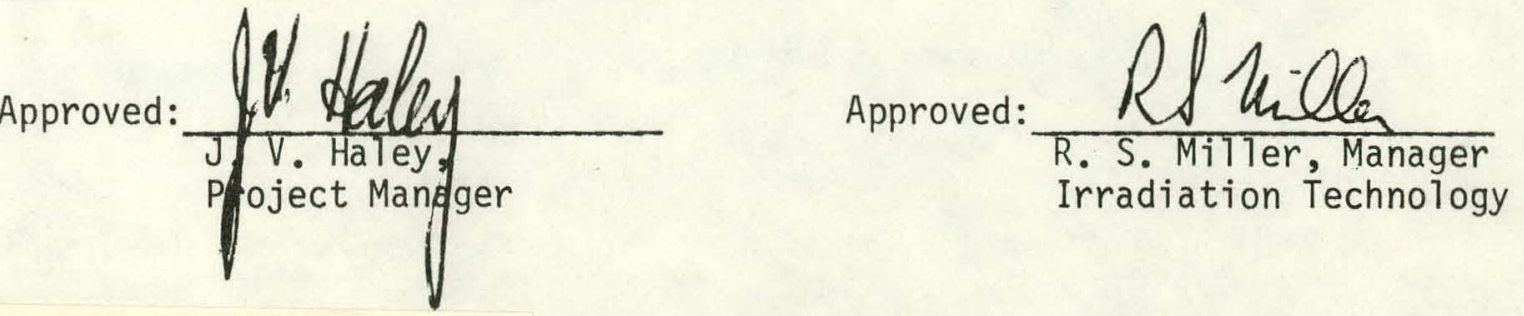

\section{LEGAL NOTICE}

This report was prepared as an account of Government sponsored work. Neither the Untted

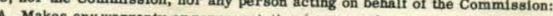

A. Makes any warranty or representation, expressed or implied, with respect to the aycuany informetton tvately owned rights; or B. Assumes any liab

with respect to the use of, or for damages resulting from the $\Lambda_{s}$ used in tho a a pparatus, method, or process disclosed in this report, pinyee or contractor of the Cominissiun, or employee of such contractor, to the any emsuch employee or contractor of the Commission, or employee of such contractor prepares, disseminates, or provides access to, any information pursuant to his employment or contract

\section{WESTINGHOUSE ELECTRIC CORPORATION} Nuclear Fuel Division

P. 0. Box 355

Pittsburgh, Pennsylvania 15230 


\section{DISCLAIMER}

This report was prepared as an account of work sponsored by an agency of the United States Government. Neither the United States Government nor any agency Thereof, nor any of their employees, makes any warranty, express or implied, or assumes any legal liability or responsibility for the accuracy, completeness, or usefulness of any information, apparatus, product, or process disclosed, or represents that its use would not infringe privately owned rights. Reference herein to any specific commercial product, process, or service by trade name, trademark, manufacturer, or otherwise does not necessarily constitute or imply its endorsement, recommendation, or favoring by the United States Government or any agency thereof. The views and opinions of authors expressed herein do not necessarily state or reflect those of the United States Government or any agency thereof. 


\section{DISCLAIMER}

Portions of this document may be illegible in electronic image products. Images are produced from the best available original document. 
LEGAL NOTICE

This report was prepared as an account of Government sponsored work. Neither the United States nor the Commission, nor any person acting on behalf of the Commission:

A. Makes any warranty or representation, expressed or implied, with respect to the accuracy, completeness, or usefulness of the information contained in this report, or that the use of any information, apparatus, method, or process disclosed in this report may not infringe privately owned rights; or

B. Assume any liabilities with respect to the use of, or for damages resulting from the use of any information, apparatus, method or process disclosed in this report.

As used in the above, "person acting on behalf of the Commission" includes: any employe or contractor of the Commission, or employe of such contractor, to the extent that such employe or contractor of the Commission, or employe of such contractor prepares, disseminates, or provides access to, any information pursuant to his employment or contract with the Commission, or his employment with such contractor. 
U. S. Atomic Energy Commission (45)

Brussels Office

APO, New York 09667

Attn: Senior AEC Representative

U. S. Atomic Energy Commission

New York Operations Office

376 Hudson Street

New York, New York 10014

Attn: Development Contracts Branch I (2)

Attn: Reports Library (1)

U. S. Atomic Energy Commission

Office of Foreign Activities, GM

Washington, D.C. 20545

U. S. Atomic Energy Commission (1)

Assistant General Counsel for Patents

Washington, D.C. 20545

U. S. Atomic Energy Commission (224)

Division of Technical Information Extension

P. O. Box 62

Oak Ridge, Tennessee 37830

U. S. Atomic Energy Commission

Brookhaven Office

Upton, L.I., New York 11973

Attn: Chief, Patent Group

U. S. Atomic Energy Commission (2)

Division of Reactor Development \& Technology

Washington, D. C. 20545

Attn: Chief, Water Reactors Branch 
This letter covers the work done during the third quarter of Calendar 1969 and is in keeping with the previously approved procedure of issuing a limited distribution quarterly progress letter, instead of a bound report, while fuel irradiation continues.

During the period work resumed in the Hot Laboratory on the destructive examination of samples from Core II fuel rods. Examination and photomicrography of five additional metallographic samples were completed. All burnup samples were dissolved and aliquots of each transferred to the Analytical Laboratories. Five burnup samples and one archive sample were analyzed. Cross-check burnup analyses indicated a bias in Westinghouse data for $\mathrm{Pu} \mathrm{U}^{239} / \mathrm{U}^{238}$ and $\mathrm{Nd}^{148} / \mathrm{U}^{238}$, necessitating a recalibration. A one-inch long section of fuel rod was gamma scanned before and after removing the fue 1 to determine the contribution of the cladding to gross gamma activity. Ring sections of cladding were analyzed for hydrogen content and $\mathrm{Mn}^{54}$ activity, the latter to determine fast flux exposure. Twenty-two tensile samples of cladding and nine burst specimens were tested.

The Saxton reactor systems were functionally checked out early in the period, and Core III achieved criticality on July 15. Zero power physics testing continued throughout most of the period and flux data were successfully reduced with the INCORE code. Initial reactor operator training and examination commitments were completed in September.

A draft of the Semi-annual Report for the Period Ending June 30, 1969, (WCAP-3385-20) was written. 
SECTION 2

POST-IRRADIATION EXAMINATION OF CORE II FUEL RODS

\subsection{Metallography}

Examination and photomicrography of the following metallographic samples were completed during the period:

1. Two grid contact areas, one of which showed significant fretting,

2. Peak heat flux region of lead Vipac rod (K4), and

3. Two samples with locally adherent corrosion product.

The examination of grid contact areas revealed normal concentration and orientation of hydrides. In addition, oxide film thicknesses were essentially the same as those on rods of similar temperature history in non-grid areas. The sample with significant fretting ( 24.25 in. from bottom of Rod K4) exhibited two fret marks, $90^{\circ}$ apart, the largest of which was $0.123^{\prime \prime}$ long, $0.116^{\prime \prime}$ wide, and $0.009 "$ deep. There was no evidence of any oxide film at the fretted surface.

The peak power section from the lead Vipac rod showed that in-pile sintering had occurred from the center to about $80 \%$ of the fuel radius. Limited columnar grain growth was also evident on this sample, indicating higher center temperatures than on pelleted rods of comparable burnup. In addition, most of the inner surface of the cladding exhibited an oxide-type layer, with apparent bonding of the fuel to the layer in many locations.

One of the pellet-fuel rods, which during visual examination showed dark patches of adherent crud, was sectioned in two locations to provide transverse samples for metallographic studies. The outer surfaces of both sections exhibited intermittent, semi-porous layers from 0.3 to $0.7 \mathrm{mil}$ thick. The thick, porous nature of these layers suggest that they are corrosion product deposits (crud), as opposed to thin, relatively high density zirconium oxide films resulting from normal oxidation of Zircaloy cladding. 
Metallographic examination of five transverse sections removed from peak power locations (three pellet rods, two Vipac samples) was started.

\subsection{Burnup Analysis}

All 34 axial burnup samples and three unirradiated archive samples were dissolved, and diluted aliquots of each were transferred to the Analytical Laboratories. A multi-reagent system assured that all residues were dissolved. Six of the samples, including one archive, were analyzed but results were not reported because of further problems in mass spectrometric analysis. Although cross check burnup analyses received from General Electric and Idaho Nuclear were in good agreement with the Westinghouse heavy element isotopic abundances, they showed a bias of $1.9 \%$ and $3.4 \%$ (high) in the Westinghouse data for $\mathrm{Pu}^{239} / \mathrm{U}^{238}$ and $\mathrm{Nd}^{148} / \mathrm{U}^{238}$, respectively. A complete re-calibration of the spike solution was started to eliminate the bias. Resolution of the problem is expected during the next quarter.

Results of the mass spectrometric analysis of the initial burnup samples were processed with the REBUF data-reducing code. (1) This code, originally developed to process data for $\mathrm{UO}_{2}$, was modified for $\mathrm{UO}_{2}-\mathrm{PuO}_{2}$ fue1. As a means of estimating rod average burnup and axial burnup distributions, the pellet burnups were correlated with gross gamma activity for several key rods. On the assumption that the burnup-gamma activity correlation is linear, the rod average burnup for each rod in the program was determined and is listed in Table 1.

Simgle and mult1-channel gamma scans of a one-inch long section from near the peak power region of Rod RI were completed. Fuel was removed from the sample, and the scans were repeated on the cladding. The results showed that the $\mathrm{Zr}-\mathrm{Nb}^{95}$ in the cladding contributed about $2 \%$ to the gross gamma activity.

(7) R. J. Nodvik, "Evaluation of Mass Spectrometric and Radiochemical Analyses of Yankee Core I Spent Fuel," WCAP-6068, March 1966. 


\subsection{Hydrogen Analyses}

Eight ring samples removed from three fuel rods were analyzed for hydrogen by hot vacuum extraction. The results, as given in Table 2, show slightly lower hydrogen levels than those obtained earlier on samples from Rod QE. The reason for the difference has not been determined, but is probably due to differences in hydrogen content at the beginning of life. Further evaluation of these data is currently in progress.

\subsection{Fast Flux Dosimetry}

Six sets of cladding samples were analyzed for $\mathrm{Mn}^{54}$ activity and iron content to determine fast flux exposure based on the $\mathrm{Fe}^{54}$ (n, p) $\mathrm{Mn}^{54}$ reaction. These samples represented six different axial positions in the highest burnup rods from Saxton Core II. The $\mathrm{Mn}^{54}$ activity measurements and the resulting fast fluence values are summarized in Table 3 .

\subsection{Mechanical Testing}

All scheduled tensile tests of cladding samples. were completed in the Mechanical Test Facility. The results, shown in Table 4, indicate similar strength levels for all samples, with no obvious correlation with fluence or location in Core II. In addition, all samples exhibited good ductility, as revealed by moderately high elongation (min. of $2.5 \%$ uniform elongation) and reduction of area (26 to $67 \%$ ).

The in-cell burst test equipment was modified to facilitate remote manipulations and improve the accuracy of the strain measurement system. The test setup was checked out, and burst tests at $675^{\circ} \mathrm{F}$ were completed on nine cladding samples. The burst strength data from these tests are shown in Table 5 . These results will be evaluated in the next semiannual report. 
SECTION 3

SAXTON OVERPOWER TEST

All operating data, core flux maps, and rod power calculations related to the overpower test were re-evaluated. As a result, the best estimate of peak 1 inear power in rods $A$ and $B$ was revised to $18.7 \mathrm{kw} / \mathrm{ft}$. A summary of the power levels achieved during various steps in the overpower test is shown in Table 6 .

The principal reasons for the reduction in linear power levels from those previous $1 y$ reported are:

1. Previous power levels contained a 1.045 engineering factor, which is not consistent with a "best estimate" basis.

2. Axial variation in fission cross sections caused an error of $\sim 4 \%$ in the measured axial power peaking factors in rods $A$ and $B$. The nominal peak linear power of $18.7 \mathrm{kw} / \mathrm{ft}$ appears to be consistent with the observed fuel microstructures in the overpower test rods. Further calculations are in progress to determine center temperatures and thermal gradients, based on the $18.7 \mathrm{kw} / \mathrm{ft}$ peak linear power. 
Functional checkout of all reactor systems was completed early in July, and Core III achieved criticality on July 15, 1969. Nuclear constants required for interpretation of Core III flux map data were generated and used in analyzing the zero power physics measurements. Comparison of flux data reduction with the CDC-6600 and an on-site computer showed good agreement.

The zero power physics measurements indicated sufficient Core III lifetime to achieve the objective of 5000 effective full power hours. They also revealed an apparent $10 \%$ over-prediction of the 1oose lattice power levels due to greater measured power sharing in the assemblies near the periphery of Core III. Alternate control rod operating modes are being considered to increase the power level in the loose lattice region.

The initial reactor operator training and examination commitments were completed. On September 19, the reactor was cooled down for repair of an instrument conoseal port. 
Table 1

Preliminary Estimate of Saxton Rod Average Burnup

\begin{tabular}{llcc} 
Rod & $\begin{array}{l}\text { Fuel } \\
\text { I.D. }\end{array}$ & $\begin{array}{l}\text { Rod Average } \\
\text { Gamma Activity, }\end{array}$ & $\begin{array}{c}\text { Estimated Rod } \\
\text { Average Burnup } \\
\text { (MWD/MTM) }\end{array}$ \\
\hline JF & Pellet & 5.898 & 16,700 \\
RI & Pellet & 5.907 & 16,700 \\
MY & Pellet & 5.905 & 16,700 \\
QE & Pellet & 7.796 & 22,100 \\
TE & Pellet & 7.800 & 22,100 \\
TI & Pellet & 6.698 & 19,000 \\
EC & Pellet & 7.284 & 20,600 \\
TT & Pellet & 7.585 & 21,500 \\
TP & Pellet & 7.451 & 21,100 \\
CH & Pellet & 7.753 & 21,900 \\
& & & \\
S1 & Vipac & 6.105 & 17,300 \\
PO & Vipac & 6.037 & 17,100 \\
K4 & Vipac & 7.722 & 21,800 \\
N3 & Vipac & 7.353 & 22,800 \\
N1 & Vipac & 7.796 & \\
& & & 19,100 \\
LA & Pellet & 6.760 & 17,400 \\
& & & 17,400 \\
A & Pellet & 7.814 & 10,600 \\
B. & Pellet & 7.798 & \\
D & Pellet & 4.485 &
\end{tabular}

Notes: (a) Referenced to January 28, 1969.

(b) Assumes 1 inear correlation of burnup and gamma activity. 
Table 2

Hydrogen in Irradiated Saxton Core II Fuel Cladding

\begin{tabular}{|c|c|c|c|}
\hline $\begin{array}{l}\text { Rod } \\
\text { Number }\end{array}$ & $\begin{array}{l}\text { Axial Location } \\
\text { of Sample, In. (a) }\end{array}$ & $\begin{array}{l}\text { Power Relative } \\
\text { to Rod Peak } \\
\end{array}$ & $\begin{array}{l}\text { Hydrogen } \\
\text { Content (b), ppm }\end{array}$ \\
\hline $\begin{array}{l}\text { TI } \\
\text { TI }\end{array}$ & $\begin{array}{r}17.6 \\
9.1\end{array}$ & $\begin{array}{l}1.00 \\
0.90\end{array}$ & $\begin{array}{l}76 \\
71\end{array}$ \\
\hline $\begin{array}{l}\text { LA } \\
\text { LA }\end{array}$ & $\begin{array}{l}17.6 \\
9.1\end{array}$ & $\begin{array}{l}1.00 \\
0.90\end{array}$ & $\begin{array}{l}80 \\
64\end{array}$ \\
\hline $\begin{array}{l}K 4 \\
K 4 \\
K 4 \\
K 4\end{array}$ & $\begin{array}{r}17.6 \\
25.1 \\
30.1 \\
3.8\end{array}$ & $\begin{array}{l}1.00 \\
0.93 \\
0.75 \\
0.60\end{array}$ & $\begin{array}{l}51 \\
54 \\
66 \\
74\end{array}$ \\
\hline $\begin{array}{l}Q E \\
Q E \\
Q E \\
Q E\end{array}$ & $\begin{array}{l}17.8 \\
25.1 \\
30.1 \\
35.1\end{array}$ & $\begin{array}{l}1.00 \\
0.93 \\
0.75 \\
0.45\end{array}$ & $\begin{array}{l}93 \\
88 \\
71 \\
78\end{array}$ \\
\hline
\end{tabular}

(a) Distance from bottom of fuel rod.

(b) Based on average of two or four determinations per ring sample. 
Table 3

Summary of Fast Flux Dosimetry, Saxton Core II Fuel Cladding

\begin{tabular}{|c|c|c|c|}
\hline $\begin{array}{l}\text { Rod } \\
\text { Number }\end{array}$ & $\begin{array}{l}\text { Axial Location } \\
\text { of Sample, In. (a) }\end{array}$ & $\begin{array}{l}\mathrm{Mn}^{54} \text { Activity, } \\
\mathrm{dpm} / \mathrm{gm} \text { of } \mathrm{Fe}\end{array}$ & $\begin{array}{c}\text { Fluence ( }>1 \mathrm{Mev}) \text {, } \\
\mathrm{n} / \mathrm{cm}^{2}\end{array}$ \\
\hline QE & 25.1 & $5.17 \times 10^{7}$ & $2.8 \times 10^{21}$ \\
\hline $\mathrm{QE}$ & 35.1 & $2.54 \times 10^{7}$ & $1.4 \times 10^{21}$ \\
\hline TT & 1.9 & $3.15 \times 10^{7}$ & $1.7 \times 10^{21}$ \\
\hline TT & 14.1 & $6.87 \times 10^{7}$ & $3.7 \times 10^{21}$ \\
\hline LA & 9.1 & $5.27 \times 10^{7}$ & $2.9 \times 10^{21}$ \\
\hline LA & 17.6 & $5.96 \times 10^{7}$ & $3.3 \times 10^{21}$ \\
\hline
\end{tabular}

(a) Distance from bottom of fuel rod 
Table 4

-ensile Test Results on Irradiated Saxton Core II Cladding

\begin{tabular}{|c|c|c|c|c|c|c|c|c|}
\hline $\begin{array}{r}\text { Sample } \\
\text { Rod No: }\end{array}$ & $\begin{array}{l}\text { Identification } \\
\text { Axial Location, } \\
\text { Inches (a) } \\
\end{array}$ & $\begin{array}{l}\text { Fluence } \\
(>1 \text { Mev }) \\
\mathrm{n} / \mathrm{cm}^{2}(\mathrm{~b})\end{array}$ & $\begin{array}{l}\text { Test } \\
\text { Tempera- } \\
\text { ture, }{ }^{\circ} \mathrm{F} \\
\end{array}$ & $\begin{array}{l}0.2 \% \text { Yield } \\
\text { Strength, } \\
\text { kpsi } \\
\end{array}$ & $\begin{array}{c}\text { Ultimate } \\
\text { Strength, } \\
\text { kps } i \\
\end{array}$ & $\begin{array}{l}\text { Uniform } \\
\text { Elonga- } \\
\text { tion, \% }\end{array}$ & $\begin{array}{l}\text { Total } \\
\text { Elonga- } \\
\text { tion, \% } \\
\end{array}$ & $\begin{array}{c}\text { Reduction } \\
\text { of } \\
\text { Area, \% } \\
\end{array}$ \\
\hline $\begin{array}{l}\text { TE } \\
\text { TI } \\
\text { TP } \\
\text { TT } \\
\text { TT } \\
\text { LA } \\
\text { LA } \\
\text { NI } \\
\text { N3 } \\
\text { TE } \\
\text { JF } \\
\text { RI } \\
\text { SI } \\
\text { SI } \\
\text { PO } \\
\text { P0 } \\
\text { PO } \\
\text { K4 } \\
\text { NI } \\
\text { N3 } \\
\text { TI } \\
\text { TP }\end{array}$ & $\begin{array}{c}9.8-16.8 \\
3.0-9.0 \\
7.0-14.0 \\
2.0-8.0 \\
8.0-14.0 \\
3.0-9.0 \\
19.8-25.8 \\
8.0-14.0 \\
8.0-14.0 \\
2.0-8.8 \\
2.0-8.8 \\
2.8-8.8 \\
2.8-8.8 \\
9.8-16.8 \\
2.0-8.8 \\
9.8-16.8 \\
29.8-37.0 \\
30.3-36.5 \\
2.0-8.0 \\
2.0-8.0 \\
19.8-25.8 \\
1.0-7.0\end{array}$ & $\begin{array}{l}3.2 \times 10^{21} \\
2.3 \times 10^{21} \\
3.1 \times 10^{21} \\
2.3 \times 10_{21}^{21} \\
3.3 \times 10^{21} \\
2.3 \times 10^{21} \\
3.1 \times 10^{21} \\
3.1 \times 10^{21} \\
3.1 \times 10^{21} \\
2.1 \times 10^{21} \\
1.7 \times 10^{21} \\
2.0 \times 10^{21} \\
2.0 \times 10^{21} \\
3.2 \times 10^{21} \\
2.0 \times 10^{21} \\
3.2 \times 10^{21} \\
1.5 \times 10^{21} \\
1.8 \times 10^{21} \\
2.1 \times 10^{21} \\
2.1 \times 10^{21} \\
3.1 \times 10^{21} \\
1.9 \times 10^{21}\end{array}$ & $\begin{array}{l}675 \\
675 \\
675 \\
675 \\
675 \\
675 \\
675 \\
675 \\
675 \\
675 \\
675 \\
675 \\
675 \\
675 \\
675 \\
675 \\
675 \\
675 \\
675 \\
675 \\
700 \\
700\end{array}$ & $\begin{array}{l}46.2 \\
54.2 \\
52.0 \\
49.1 \\
48.4 \\
48.4 \\
52.5 \\
51.6 \\
54.3 \\
67.0 \\
40.1 \\
56.9 \\
48.2 \\
56.7 \\
53.2 \\
42.3 \\
52.2 \\
48.3 \\
49.3 \\
45.8 \\
53.8 \\
44.8\end{array}$ & $\begin{array}{l}54.2 \\
61.7 \\
59.6 \\
57.9 \\
54.6 \\
58.1 \\
60.4 \\
64.8 \\
65.3 \\
73.1 \\
45.9 \\
65.9 \\
58.2 \\
67.8 \\
72.4 \\
62.0 \\
61.6 \\
52.0 \\
63.3 \\
59.2 \\
57.3 \\
53.8\end{array}$ & $\begin{array}{r}3.6 \\
5.2 \\
2.5 \\
6.0 \\
2.6 \\
7.1 \\
4.9 \\
5.6 \\
5.7 \\
2.9 \\
11.5 \\
6.1 \\
7.2 \\
3.6 \\
7.3 \\
3.5 \\
4.0 \\
3.3 \\
4.8 \\
4.1 \\
4.3 \\
4.2\end{array}$ & $\begin{array}{r}9.3 \\
9.3 \\
6.0 \\
11.3 \\
8.0 \\
15.1 \\
9.8 \\
18.4 \\
14.9 \\
12.2 \\
13.6 \\
19.5 \\
19.3 \\
7.9 \\
12.5 \\
11.1 \\
8.9 \\
10.4 \\
8.6 \\
10.1 \\
9.0 \\
18.2\end{array}$ & $\begin{array}{l}27 \\
48 \\
44 \\
31 \\
53 \\
50 \\
26 \\
46 \\
56 \\
48 \\
44 \\
53 \\
37 \\
37 \\
65 \\
67 \\
49 \\
64 \\
37 \\
58 \\
36 \\
60\end{array}$ \\
\hline
\end{tabular}

(a) Distance of specimen ends from bottom of rod.

(b) Interpolated fluence at center of sample, based on data in Table 3. 


\section{Table 5}

Burst Test Results on Irradiated Saxton Core II Cladding

\begin{tabular}{|c|c|c|c|c|}
\hline $\begin{array}{l}\text { Rod } \\
\text { Number } \\
\end{array}$ & Sample & $\begin{array}{l}\text { Identification } \\
\text { Axial Location, } \\
\text { Inches } \\
\end{array}$ & $\begin{array}{c}\begin{array}{c}\text { Fluence } \\
n / \mathrm{cm}^{2}(\mathrm{~b})\end{array} \\
\end{array}$ & $\begin{array}{c}\text { Burst Strength } \\
\text { kpsi }\end{array}$ \\
\hline TE & & $19.8-27.8$ & $3.0 \times 10^{21}$ & 60.4 \\
\hline TI & . & $25.8-33.8$ & $2.2 \times 10^{21}$ & 75.0 \\
\hline TP & & $22.0-30.0$ & $3.0 \times 10^{21}$ & 74.4 \\
\hline TT & $\therefore$ & $20.5-28.5$ & $3.4 \times 10^{21}$ & Leaked \\
\hline $\mathrm{TT}$ & & $28.5-36.5$ & $2.2 \times 10^{21}$ & 48.0 \\
\hline LA & & $9.5-17.5$ & $3.2 \times 10^{21}$ & 70.0 \\
\hline$L A$ & . & $25,8-33.8$ & $2.2 \times 10^{21}$ & 63.2 \\
\hline $\mathrm{N} T$ & & $21.0-29.0$ & $3.3 \times 10^{21}$ & 76.8 \\
\hline N3 & & $21.0-29.0$ & $2.8 \times 10^{21}$ & 39.2 \\
\hline
\end{tabular}

(a) Distance of Sample ends from bottom of rod.

(b) Interpolated fluence at center of sample, based on data in Table 3. 
Table 6

Overpower Test Rod Operating History

\begin{tabular}{|c|c|c|}
\hline Period & Reactor Power, MWt & $\begin{array}{l}\text { Best Estimate } \\
\text { Test Rod } \\
\text { Peak Power, } \mathrm{kw} / \mathrm{ft} \\
\end{array}$ \\
\hline July 2-3 & Escalating & $0-15,9$ \\
\hline July $4-11$ & 22.3 & 15.8 \\
\hline August $9-11$ & 21.8 & 15.4 \\
\hline August 13-19 & 22.6 & 15.9 \\
\hline August $19-23$ & 25.6 & 17.7 \\
\hline September $3-6$ & 22.6 & 15.9 \\
\hline September $6-21$ & 25.6 & 17.7 \\
\hline October $17-18$ & 26.7 & 18.7 \\
\hline
\end{tabular}

